\title{
Bibliotekarze na rynku pracy - omówienie badań ankietowych
}

STReszczenie. Wiosną 2009 roku przeprowadzono anonimowe badania ankietowe wśród polskich bibliotekarzy i studentów bibliotekoznawstwa. Celem badań było poznanie opinii na temat zawodu bibliotekarza, jego miejsca na rynku pracy i oczekiwań pracowników i przyszłych bibliotekarzy związanych z wynagrodzeniem za pracę. W badaniach uczestniczyło ponad 1000 osób, w różnym wieku, ze wszystkich niemalże regionów Polski. Duża liczba odpowiedzi na pytania półotwarte umożliwiła dokładniejsze zrozumienie odczuć i intencji respondentów.

SŁowA KLuczowE: zawód bibliotekarza, rynek pracy, badania ankietowe

Sytuacja bibliotekarzy w Polsce nie jest obecnie zadowalająca. Można to zauważyć, przeglądając chociażby czasopisma zawodowe lub wpisy na forach czy blogach. Pojawiające się z rzadka opinie w prasie ogólnej czy komentarze w mediach tylko to potwierdzają. Z jednej strony otoczenie postrzega pracę $\mathrm{w}$ bibliotece jako zajęcie nieciekawe, słabo opłacane, bez perspektyw, nie orientując się zupełnie, na czym ta praca polega. Z drugiej strony oczekuje się od bibliotekarzy dużej wiedzy, zaangażowania, ciągłego doskonalenia się, aby sprostać aktualnym wymaganiom i nadążyć za szybkim rozwojem cywilizacji. Jak naprawdę wygląda praca w tym zawodzie, wiedzą tylko ci, którzy ją wykonują. Aby poznać szerzej opinie dotyczące sytuacji bibliotekarzy oraz przekonać się, co oni sami sądzą o sobie i o wykonywanym zawodzie, jakie mają problemy i co sprawia, że go jednak wykonuja, poproszono bibliotekarzy w Polsce o wypełnienie ankiety. 


\section{Metoda przeprowadzenia badań ankietowych}

\section{Cel i przedmiot badań}

Anonimowa ankieta pod nazwą „Pierwsze kroki w zawodziebibliotekarza” skierowana była do pracowników wszystkich typów bibliotek, do studentów bibliotekoznawstwa, a także innych kierunków. Warunkiem jej wypełnienia był jakikolwiek związek z pracą w bibliotece - obecnie lub w przeszłości. Pytania przygotowane zostały głównie pod kątem młodych pracowników bibliotek w celu poznania ich opinii na temat wykonywanego zawodu. Aby jednak możliwe było porównanie ich obecnej sytuacji na rynku pracy, możliwości finansowych i oczekiwań, proszono także o wypełnienie ankiety osoby z dłuższym stażem oraz doświadczeniem zawodowym. Układając pytania ankietowe, zakładano, że opinie młodych osób rozpoczynających życie zawodowe mogą różnić się od poglądów wieloletnich pracowników bibliotek. Aby zachęcić do głębszych refleksji, nie ograniczano odpowiedzi jedynie do formy zamkniętej, w wielu przypadkach zastosowano możliwość poszerzenia opinii w polu do swobodnych sformułowań. Możliwość ta została w pełni wykorzystana przez respondentów - uzyskano 2661 wolnych wypowiedzi w ośmiu pytaniach półotwartych, spośród nich wybrano i dość licznie zacytowano najciekawsze. Na wiele pytań można było odpowiadać, stosując zasadę multiwariantowości, co pozwoliło na szczegółowe zdefiniowanie opinii.

\section{Metoda pomiaru danych}

Zastosowano metodę zbierania danych od respondentów za pomocą ankiety internetowej. Jest to obecnie jedna z najnowszych sondażowych metod pomiarów pośrednich, ponieważ rozwija się ona równolegle z rozwojem Internetu. W tym celu połączono dwa sposoby pozyskiwania danych: formularz ankiety był widoczny w Internecie, a informację o nim dodatkowo rozesłano pocztą elektroniczną. Metoda internetowa ma istotną zaletę w porównaniu z metodami tradycyjnymi - jest znacznie mniej pracochłonna, ponieważ dane łatwo przetworzyć i można wybrać najlepszy sposób ich zaprezentowania.

Formularz ankiety został umieszczony na serwerze Biblioteki Głównej i Ośrodka Informacji Naukowo-Technicznej Politechniki Wrocławskiej. Link wraz z prośbą o wypełnianie wysłano do internetowego portalu dla bibliotekarzy EBIB (Serwis Elektroniczna Biblioteka). Równolegle do 68 polskich instytucji (Biblioteka Narodowa, akademickie ośrodki kształcenia bibliotekarzy, duże biblioteki akademickie, biblioteki Państwowej Akademii Nauk i biblioteki publiczne) przesłano list pocztą elektroniczną z prośbą o rozpropagowanie badań wśród swoich pracowników. 


\section{Struktura ankiety}

Ankieta składała się z 21 pytań, które można pogrupować w następujący sposób:

- celem pierwszych siedmiu pytań było poznanie respondenta, jego obecnego statusu (student, pracownik), miejsca pracy oraz odbytego stażu i stosunku pracy, a także aktywności zawodowej w czasie trwania studiów;

- dwa pytania dotyczyły rynku pracy - sposobów szukania pracy oraz oceny ich skuteczności;

- dziewięć kolejnych pytań związanych było z podejmowaniem decyzji odnośnie do zawodu bibliotekarza: przesłanki jego wyboru, przyczyny ewentualnej zmiany pracy, wynagrodzenie i zawodowe plany na przyszłość;

- trzy ostatnie pytania stanowiły metryczkę.

\section{Aktywność respondentów w poszczególnych regionach Polski z uwzględnieniem wielkości populacji}

Od 3 marca do 10 kwietnia 2009 roku internetową stronę z formularzem ankiety odwiedziły 2564 osoby, a ankietę wypełniło 1009 respondentów.

Wypełnione formularze spływały ze wszystkich stron Polski (rys. 1). Najwięcej odpowiedzi było z Warszawy (166), Krakowa (102), Wrocławia

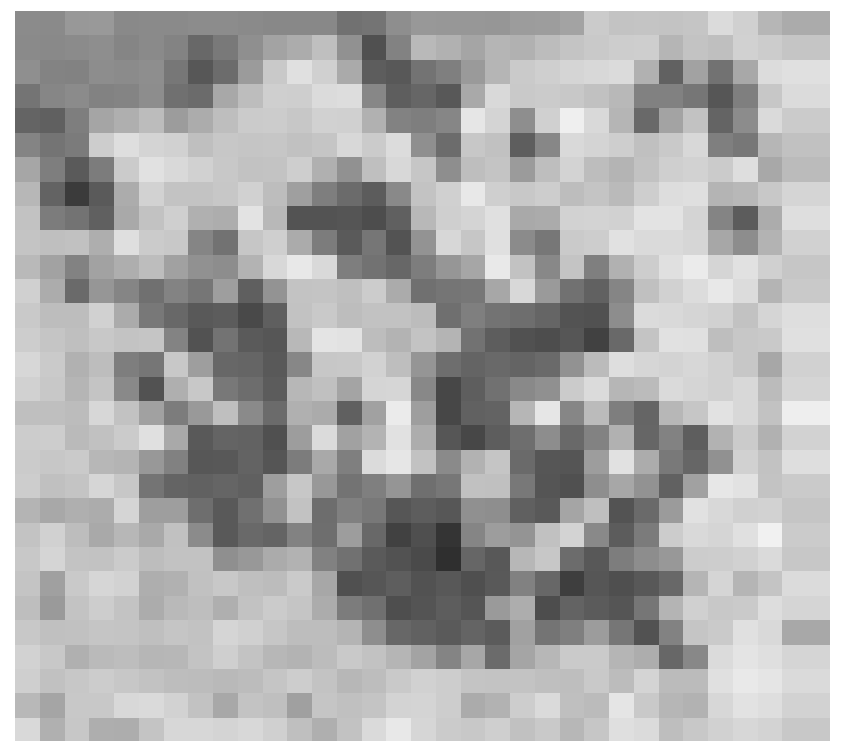

Rys. 1. Miejsca, z których zostały wysłane ankiety 
(82), Łodzi (62), Torunia (51), Gdańska (38), Olsztyna (32), Bydgoszczy (27), Poznania (26). Nie zabrakło głosów z mniejszych miast, jak Oleśnica, Jawor, Opoczno oraz małych miejscowości - Wola Krzysztoporska, Susz, Rymanów, Stare Babice, a nawet z małej wioski Szypliszki w województwie podlaskim.

Wykres (rys. 2) przedstawia kształtowanie się liczby respondentów w zależności od wielkości miejscowości, w której zlokalizowana jest biblioteka.

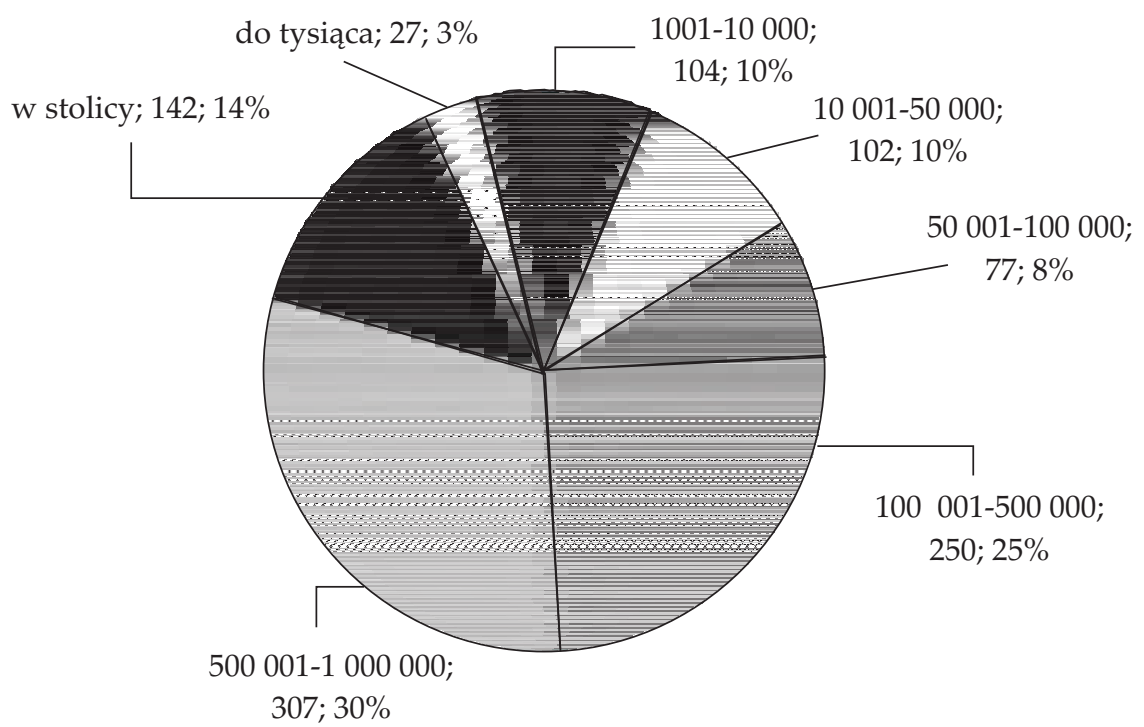

Rys. 2. Liczba respondentów w zależności od wielkości miejscowości, w której zlokalizowana jest biblioteka

\section{Omówienie odpowiedzi na pytania ankiety}

\section{Charakterystyka respondentów}

Wśród 1009 respondentów (878 kobiet i 131 mężczyzn) najliczniejszą grupę stanowią pracownicy bibliotek - 80\%, 12\% studiuje bibliotekoznawstwo i jednocześnie pracuje. Pozostałe grupy to studenci bibliotekoznawstwa $(4 \%)$ oraz osoby pracujące $\mathrm{w}$ bibliotece i studiujące inny kierunek (4\%) (rys. 3). Ankietowani podawali informację o swoim wieku (rys. 4). Przystępując do analizy wyników ankiety, respondentów podzielono umownie na dwie grupy:

$$
\begin{aligned}
& \text { A - do } 30 \text { lat; } 419 \text { osób (41\%), } \\
& \text { B - powyżej } 30 \text { roku życia; } 590 \text { osób (59\%). }
\end{aligned}
$$




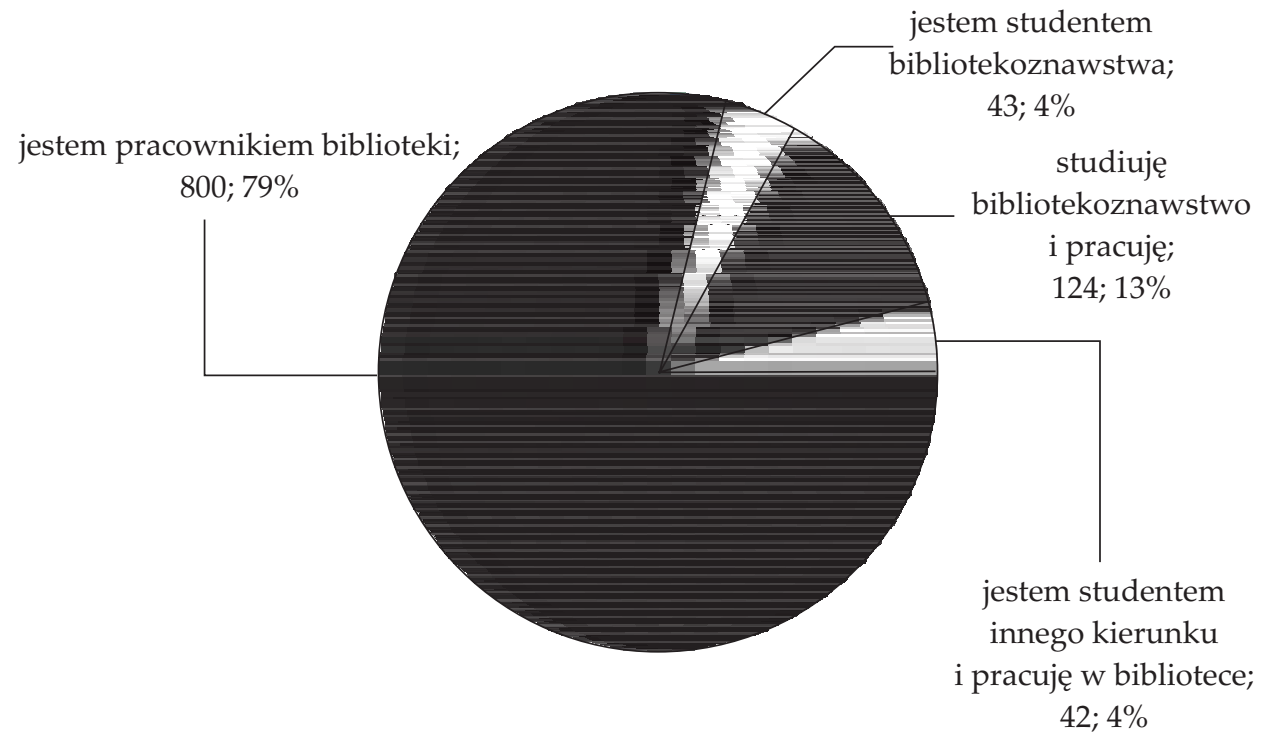

Rys. 3. Informacja o respondentach

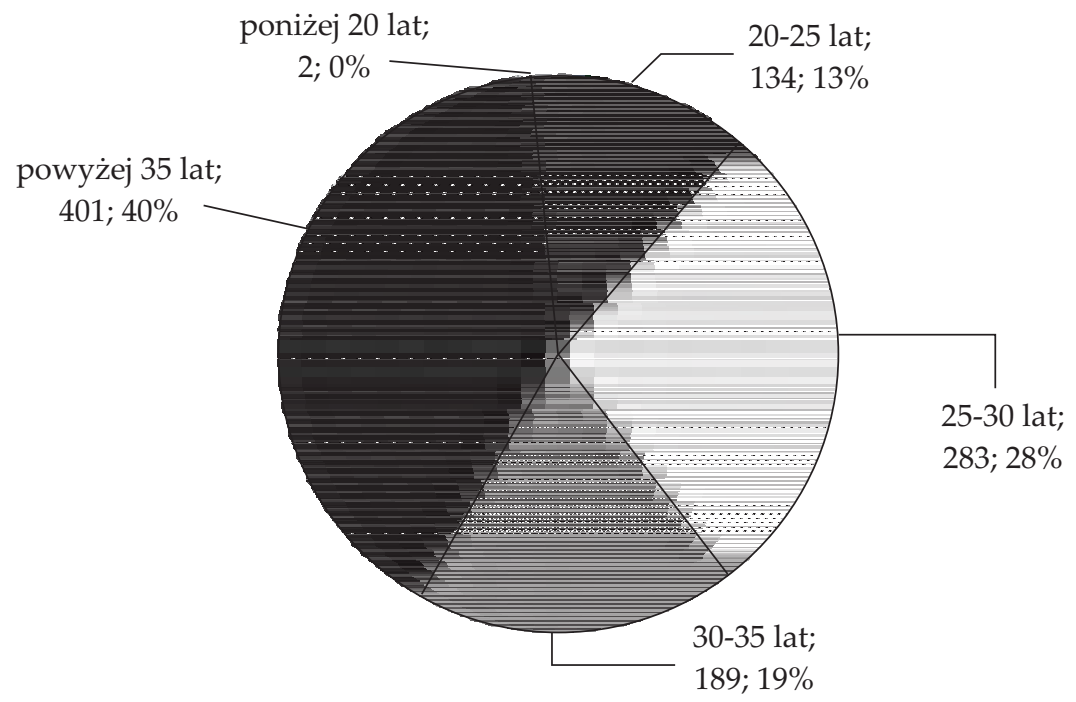

Rys. 4. Wiek respondentów

Ponad 95\% ogólnej liczby ankietowanych to osoby pracujące w bibliotekach (rys. 5). Wykres przedstawia udział procentowy wszystkich respondentów zatrudnionych w poszczególnych typach bibliotek. W grupie A (do 30 roku życia) pracuje niewiele ponad 89\%. Ich miejsce pracy to najczęściej biblioteki uczelniane (49\%) i publiczne (28\%). Pozostałe osoby są zatrudnione w bibliotekach szkolnych (3\%), pedagogicznych $(2 \%)$, 
PAN-owskich (1\%) i w innych bibliotekach (6\%). W grupie B (powyżej 30 roku życia) najwięcej osób pracuje w bibliotekach akademickich (46\%) i publicznych (40\%), ponadto: w bibliotekach szkolnych $(3 \%)$, pedagogicznych $(2 \%)$, PAN-owskich (1\%) i w innych (7\%). W tej grupie obecnie nie pracuje $\mathrm{w}$ bibliotece $1 \%$ respondentów.

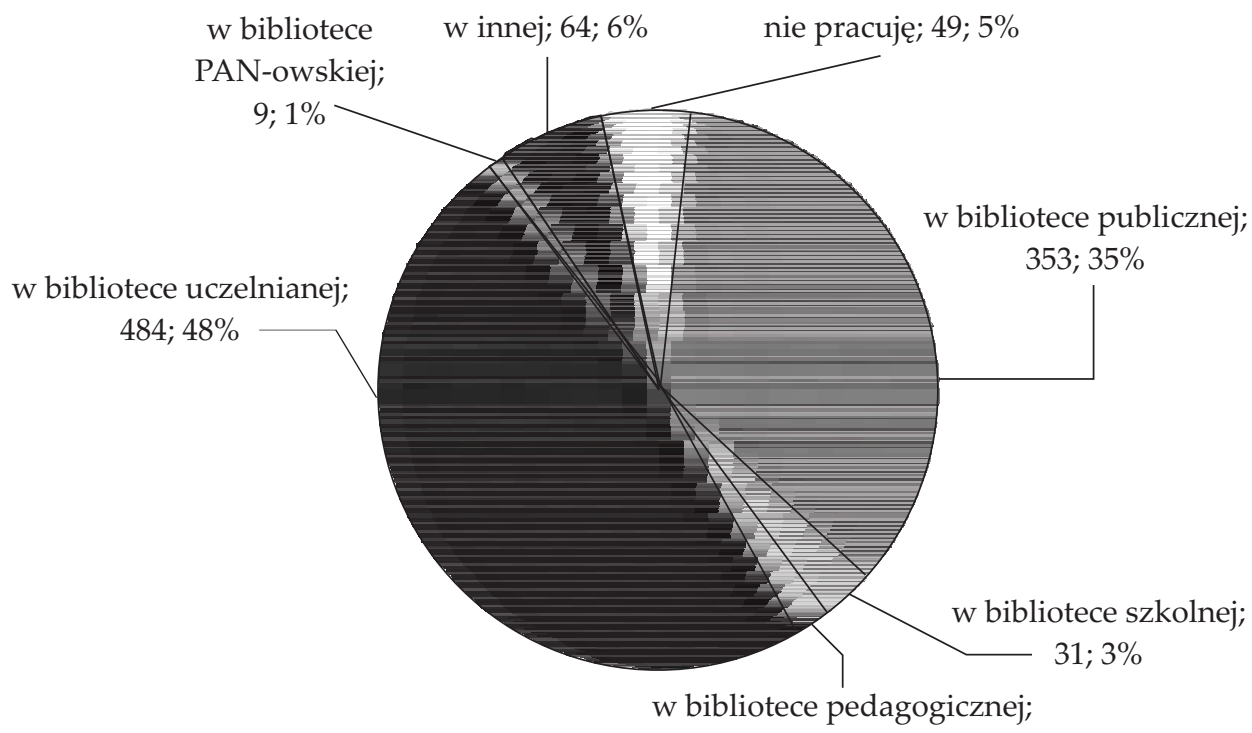

Rys. 5. Czy obecnie pracujesz w bibliotece? W jakiej?

$19 ; 2 \%$

Na pytanie „czy jest to twoja pierwsza praca w bibliotece?" twierdząco odpowiedziało $65 \%$ wszystkich respondentów - w grupie A - 67\%, a w grupie B $-63 \%$.

Wykres dotyczący okresu zatrudnienia w bibliotece układa się proporcjonalnie do wieku respondentów (rys. 6). Największy procent młodych bibliotekarzy (grupa A), prawie 37\%, pracuje od 2 do 5 lat, mniej niż 1 rok około 28\%, 1-2 lata - 24\%, 5-10 lat - 10\%, najmniej osób, niespełna $1 \%$, pracuje powyżej 10 lat. W grupie B około $61 \%$ ankietowanych pracuje w bibliotece dłużej niż 10 lat, 21\% pracuje w niej od 2 do 5 lat.

Zdecydowana większość (68\% ogółu badanych i $72 \%$ w grupie A) $\mathrm{w}$ czasie trwania nauki pracowało bądź pracuje nadal w różnych miejscach. Najwięcej osób w obu grupach wiekowych jako miejsce pracy podawało bibliotekę, tylko niecałe $2 \%$ zatrudnionych było w wydawnictwie, natomiast w innym miejscu 16\% w grupie A i $27 \%$ w grupie B. Niewiele, bo $4 \%$ wszystkich ankietowanych pracowało $\mathrm{w}$ czasie trwania studiów w dwóch lub trzech miejscach (rys. 7). 


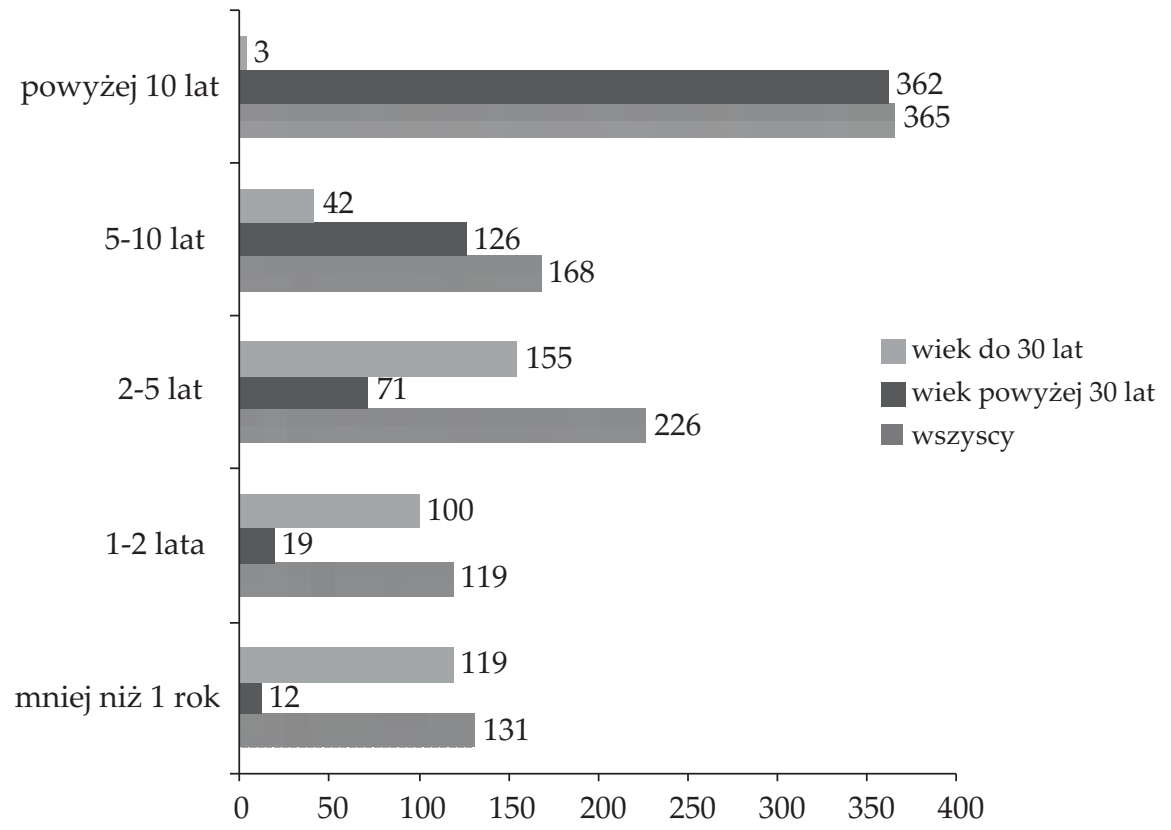

Rys. 6. Jak długo pracujesz w bibliotece?

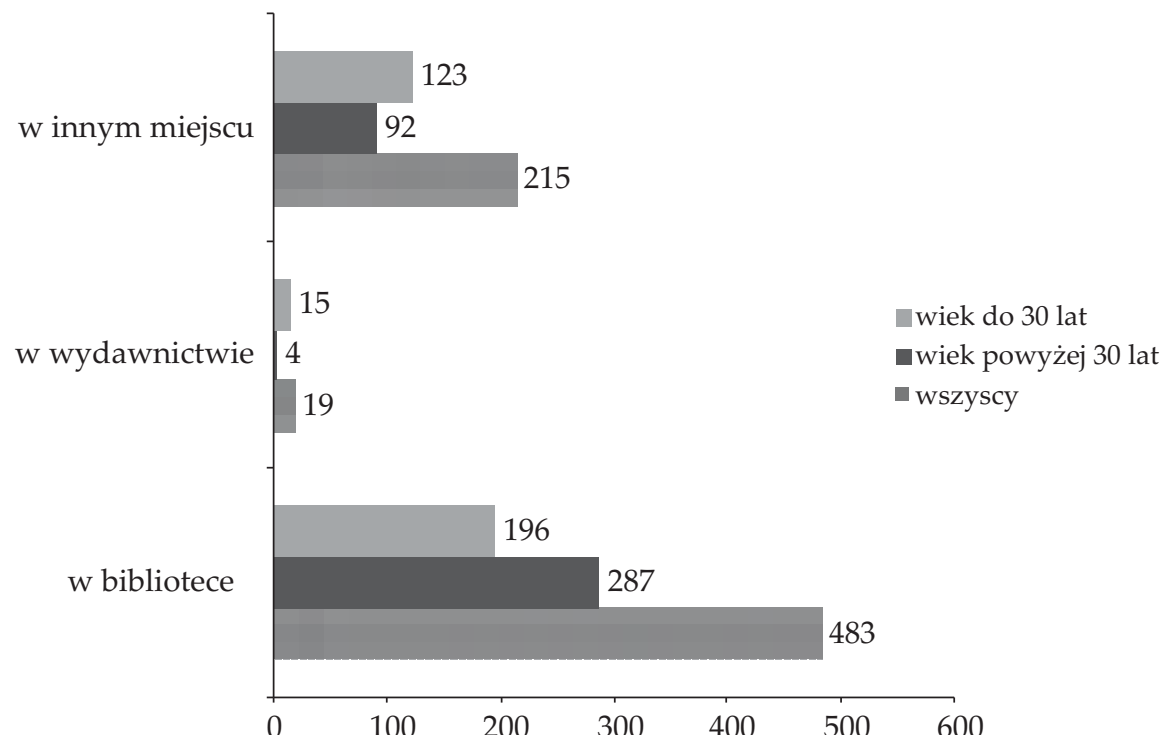

Rys. 7. Czy w czasie trwania nauki pracowałeś? Gdzie? 
Stosunek pracy wszystkich respondentów przedstawia wykres (rys. 8).

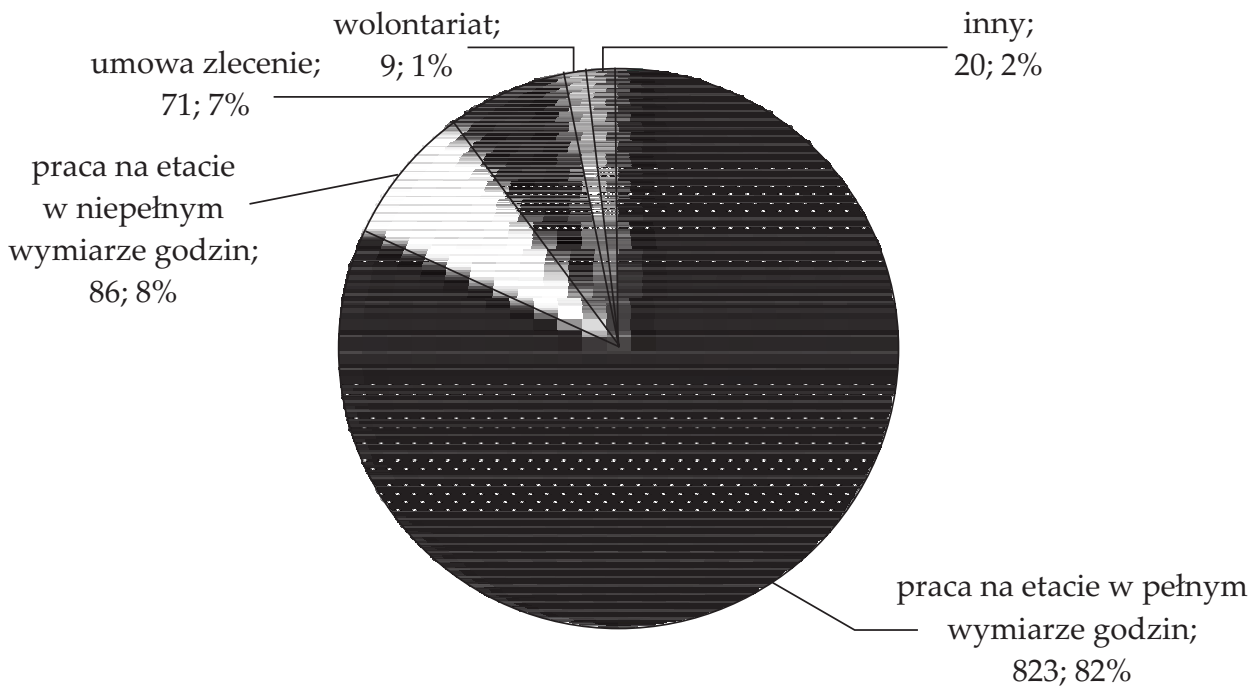

Rys. 8. Jaki jest/był Twój stosunek pracy?

Analiza w poszczególnych grupach wykazała, że w grupie A tylko 69\% zatrudnionych jest (lub było) na pełnym etacie, 13\% w niepełnym wymiarze godzin, $13 \%$ na umowę zlecenie, $1 \%$ to wolontariusze i $4 \%$ pracujący $\mathrm{w}$ innej formie, np. doraźnej bezinteresownej pomocy w zaprzyjaźnionej bibliotece. W grupie B ponad $90 \%$ badanych pracuje lub pracowało na etacie w pełnym wymiarze godzin, a 5\% w niepełnym wymiarze. Pozostałe 3\% w formie umowy zlecenia, 1\% wolontariatu i 1\% w innym charakterze.

\section{Rynek pracy}

Metody poszukiwania i sposoby efektywnego znajdowania pracy to temat następnych dwóch pytań (rys. 9). W obu przypadkach najczęściej podawano kontakty przez znajomych lub rodzinę. I jak się okazało, była to metoda najbardziej skuteczna. Dobre rezultaty widoczne są w grupie B przy stosowaniu metody poszukiwania pracy za pomocą tablic ogłoszeniowych - ponad 50\%. Często wykorzystywaną metodą były poszukiwania przez Internet. Warto także zwrócić uwagę na portal EBIB Praca. Jego skuteczność wynosiła około 25\%. Znacznie gorzej wypadły inne portale pośredniczące w poszukiwaniu pracy. Wiele osób poszukiwało zatrudnienia na targach pracy i w prasie, lecz sposoby te w niewielu wypadkach dawały pozytywne rezultaty. 


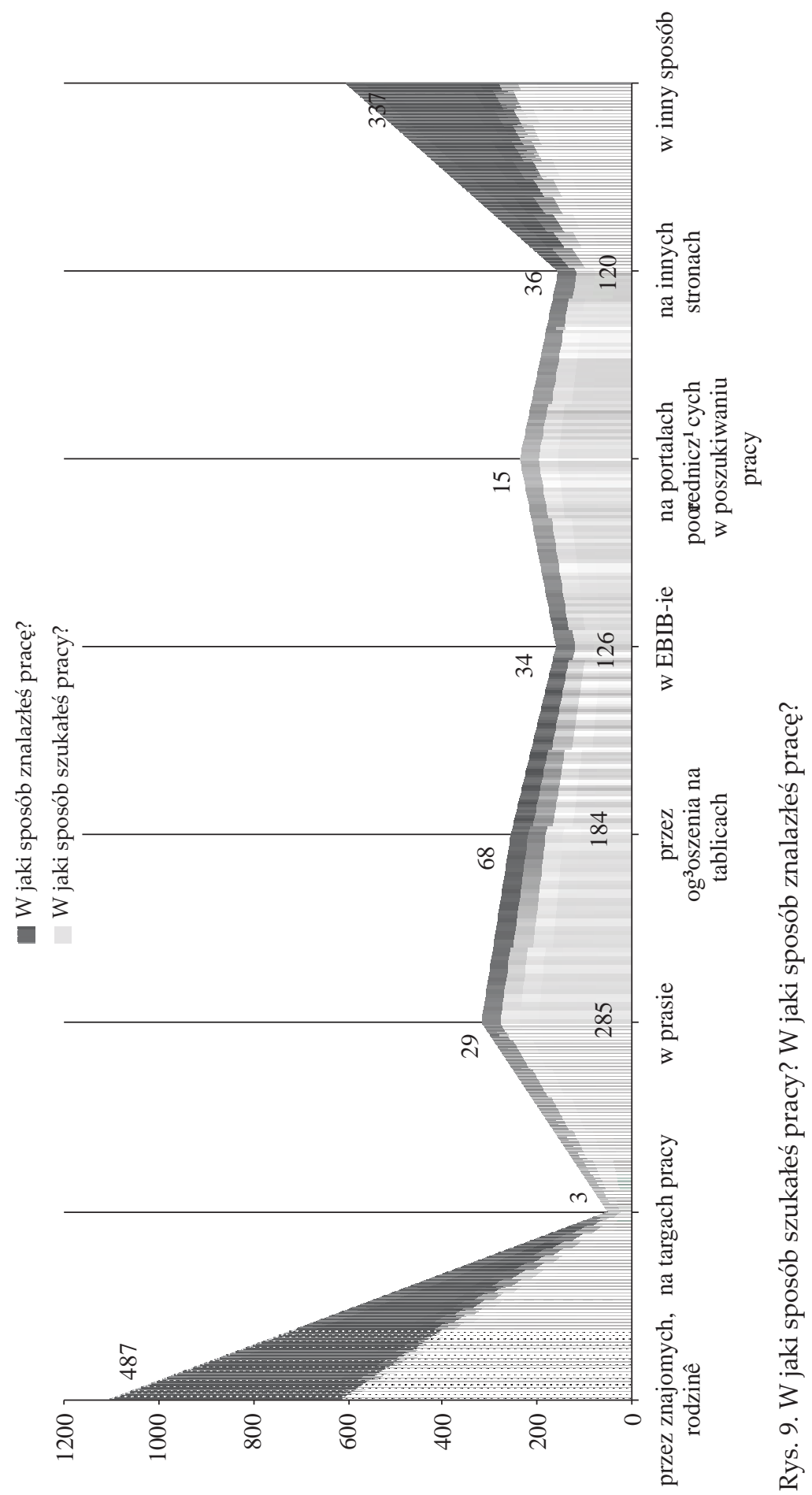


W kilku odpowiedziach na pytania widać wyraźne różnice w metodach szukania i znajdowania pracy między grupą A i B (rys. 10, 11). Osoby z grupy A częściej korzystały z możliwości Internetu, wchodząc na portale pośredniczące $w$ poszukiwaniu pracy, do EBIB-u i na inne strony. Natomiast osoby z grupy B najczęściej korzystały z kontaktów rodzinnych i szukały pracy przez znajomych i rodzinę.

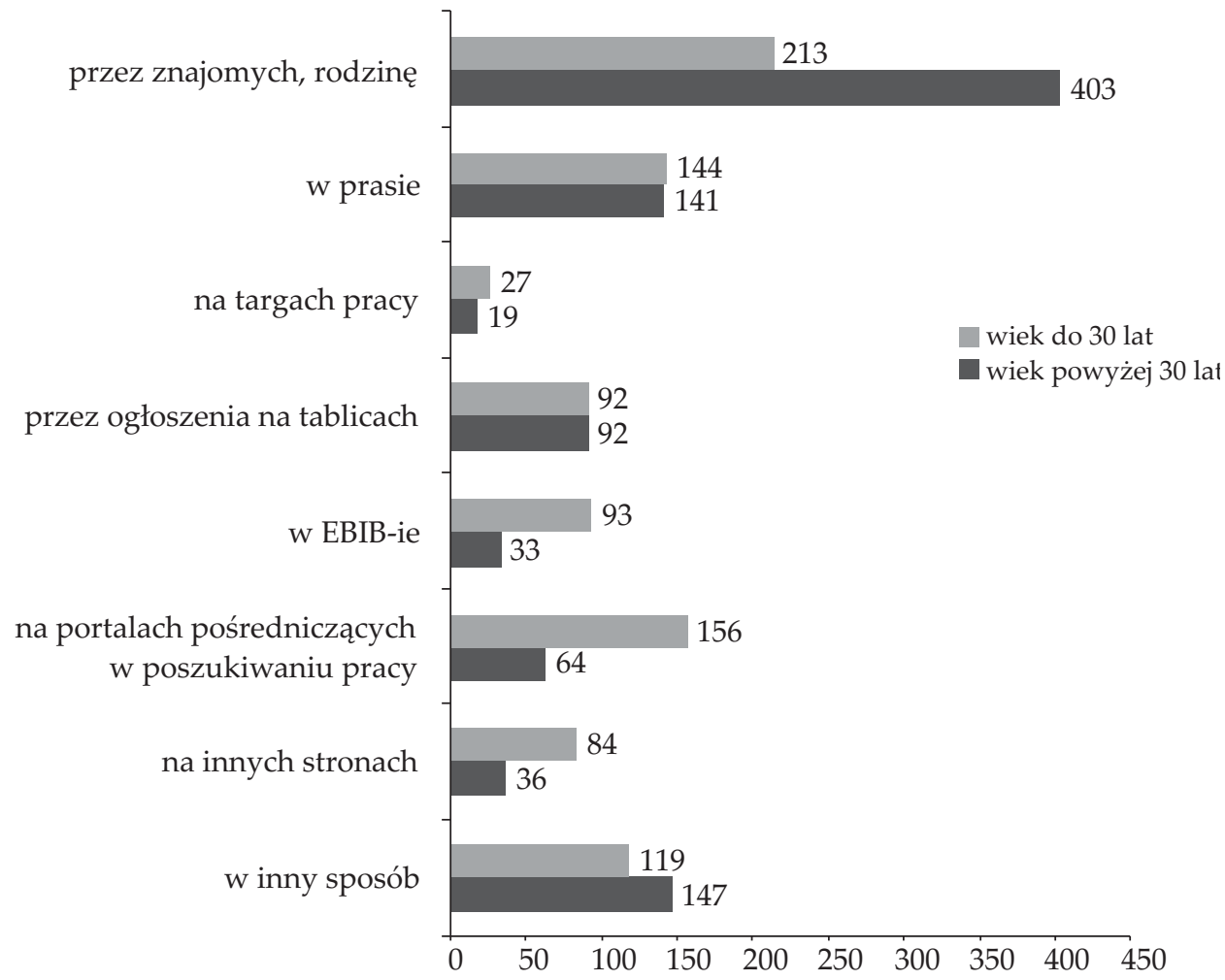

Rys. 10. W jaki sposób szukałeś pracy?

Obie grupy posługiwały się także innymi metodami, o których mówiły w swobodnej formie wypowiedzi. Najczęściej podejmowane działania to: wysyłanie CV bezpośrednio do dyrekcji biblioteki, telefonowanie lub osobiste odwiedzanie placówek i pozostawianie tam swoich aplikacji, korzystanie z pośrednictwa urzędów pracy, urzędów gminy, kuratoriów oświaty, uczelnianych biur karier, a także udział w konkursach na kierownika i pracownika biblioteki. Studenci i abiturienci otrzymywali pracę w bibliotece po odbytym stażu, praktyce zawodowej lub wcześniejszej pracy w formie wolontariatu czy umowy zlecenia. Nierzadko pomagali im uzyskać pracę wykładowcy prowadzący zaję- 


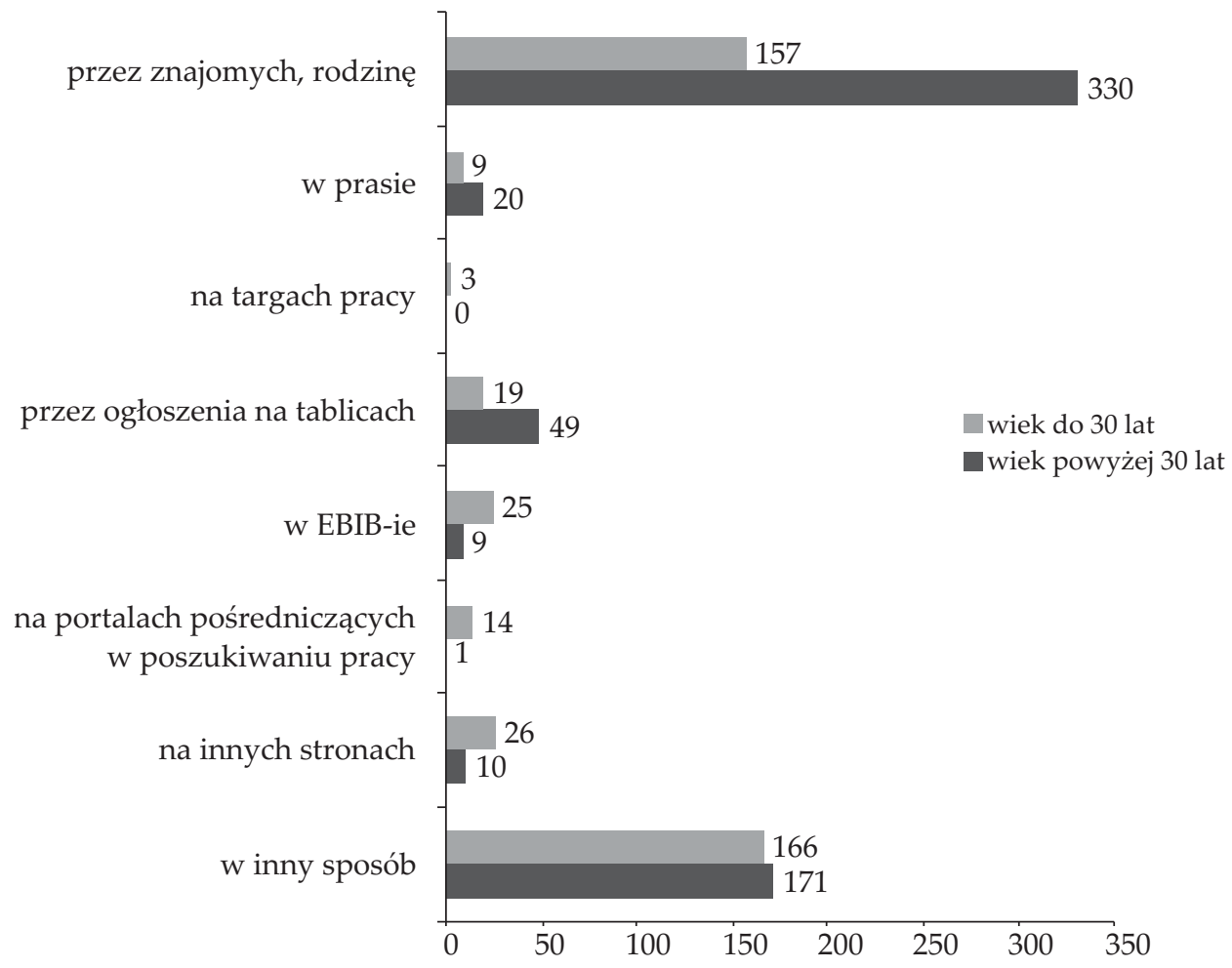

Rys. 11. W jaki sposób znalazłeś pracę?

cia na studiach bibliotekoznawczych lub zwierzchnicy z poprzednich miejsc pracy, przekazujący informacje o wakatach. Część aplikantów działało z silną determinacją: „odwiedzałam osobiście z CV wszystkie interesujące mnie biblioteki”, "wysyłałam CV do wszystkich bibliotek w okolicy”, "nawiązując kontakt ze wszystkimi instytucjami kultury w mieście aktualnego zamieszkania”, „ciągłe dopytywanie się”, „po prostu chciałam pracować w tej bibliotece i zgłosiłam się z CV na rozmowę kwalifikacyjną”, ,poszłam na studia, aby pracować w TEJ bibliotece”, "najpierw pracowałam na stażu w tej bibliotece, a następnie po kilku miesiącach, gdy zwolniło się miejsce, zostałam zatrudniona. Oczywiście, co miesiąc przypominałam się Pani Dyrektor".

Przyjęcie do pracy część przyszłych bibliotekarzy traktowała zupełnie zwyczajnie: „zwolnił się etat”, ,przyszłam i zostałam zatrudniona”, „nie szukałam, skorzystałam z oferty”, „,wcześniej byłam czytelniczką biblioteki, w której obecnie pracuję i w której w międzyczasie zwolnił się etat", , to był rok 1969 - otrzymałam pracę z nakazu”, ,propozycja pracy wypłynęła od pracodawcy”, ,nie szukałam pracy, nie zdążyłam. Już na studiach dostałam ofertę pracy w zawodzie”, ,zupełnie przypadkiem zaniosłam po- 
danie do biblioteki i akurat potrzebowali bibliotekarza”, „był wolny etat, ponieważ pracownik odchodził na emeryturę".

Dla niektórych o pozyskaniu pracy zadecydował przypadek: "gdy podpisywałam tzw. obiegówkę, panie w bibliotece podpowiedziały mi możliwość przyjęcia na staż", ,zostałam zwerbowana przez przypadek podczas poszukiwania materiałów do pisania pracy dyplomowej”, "szczęśliwy traf, wstąpiłam do biblioteki, rozmowa z dyrektorem i po dwóch tygodniach telefon, że dostałam pracę”, ,początkowo było to poszukiwanie zarobku, żeby uzyskać pieniądze na wakacje”, ,"zastępcza służba wojskowa”, a dla innych była to praca wymarzona: „dyrektorka biblioteki wiedziała od dawna o moich marzeniach o pracy w bibliotece, a ponieważ wkrótce po mojej maturze zwiększono liczbę etatów w tej bibliotece, zaproponowała mi pracę, z czego chętnie skorzystałam, choć przez 2 lata było to tylko $1 / 2$ etatu".

Na pytanie „czy lubisz swoją pracę?” twierdząco odpowiedziało 91\%, przecząco 9\% ogółu ankietowanych. Ciekawy jest natomiast fakt, że w podziale na grupy A i B odpowiedzi negatywnych było odpowiednio 12\% i 7\%. Przy każdej z odpowiedzi umieszczono prośbę o uzasadnienie. Pole nie było obowiązkowe, mimo to prawie wszyscy (955 respondentów) podzieliło się swoją opinią na ten temat. Osoby, które twierdziły, że lubią swoją pracę, najczęściej podawały, że praca ta sprawia im satysfakcję, przyjemność, daje stabilizację, rozwija, jest różnorodna, wszechstronna, kształcąca, twórcza i ciekawa, zgodna z zainteresowaniami. Podkreślały, że spełniają się w niej zawodowo, widzą w niej sens, ważny jest dla nich kontakt z użytkownikiem, a także możliwość pracy w wyuczonym zawodzie i w miłym zespole z ciekawymi ludźmi. Dużym atutem było usytuowanie biblioteki niedaleko miejsca zamieszkania oraz fakt, że nie muszą zabierać pracy do domu. Uzasadniały swój wybór także w następujący sposób: „jest to praca niestresująca, dobra dla osób posiadających rodzinę", ,jest to zawód, który zawsze chciałam wykonywać”, "motywuje mnie do działania i rozwoju”, ,mimo że kształciłam się w zupełnie innym zawodzie, to praca w bibliotece przynosi mi dużo satysfakcji i zadowolenia. Odnajduję się w niej”, "chociaż zostałam bibliotekarzem trochę przez przypadek, myślę, że znalazłam swoje miejsce i staram się być dobra w tym, co robię", „wybrałam ten kierunek studiów nieprzypadkowo, książki zawsze były moją pasją", ,kierownictwo sprzyja memu rozwojowi”, „[praca] daje mi poczucie, że jestem potrzebny”, ,wyszukiwanie informacji, to moja pasja. Cieszy mnie zadowolenie i podziw użytkowników z moich umiejętności”, "doskonale pasuje do mojego trybu życia (studia, częste wyjazdy itp.)”, „daje mi możliwość łączenia 
pracy samodzielnej z pracą zespołową", „,odpowiada mi jej spokojny charakter, nie lubię wyścigu szczurów".

Nierzadko uzasadniały swoją decyzję szerzej, widząc wiele pozytywnych aspektów pracy:

Jest ciekawa, ponieważ pracuję w małej placówce i wykonuję wszystkie rodzaje prac bibliotecznych; pozwala mi na ustawiczne zdobywanie nowej wiedzy i motywuje do ciągłego rozwoju.

Spełniam się w niej całkowicie, daje mi dużo satysfakcji, a co za tym idzie przekłada się na zadowolenie również w życiu osobistym. W moim przypadku to już drugie pokolenie bibliotekarzy (mama, a obecnie ja i siostra). Czekamy na dalszy rozwój zainteresowań bibliotekarskich w rodzinie!!!

Mając 15 lat, prowadziłam już samodzielnie Punkt Biblioteczny. Wiedziałam, że jest to moje powołanie, pozwala mi na zestawienie teorii wykładanej na uczelni z rzeczywistością; uczę się wielu nowych i przydatnych rzeczy.

Fantastyczny kierownik oddziału - potrafi zmotywować do działania, docenić, doświadczeni współpracownicy, którzy, z jednej strony chętnie dzielą się swoją wiedza, a z drugiej chętnie wykorzystują nowe rozwiązania i nie widzą niczego złego w zapytaniu o zdanie młodszego, niedoświadczonego pracownika.

Mogę prowadzić szeroką działalność kulturalną. Organizuję spotkania autorskie, różnego rodzaju warsztaty, wystawy, duże imprezy czytelnicze itp. Piszę również projekty, by pozyskać fundusze. Moje starania, nabyte doświadczenie oraz osobowość są zauważane i doceniane, zarówno pochwałami słownymi, jak i finansami.

Dużym plusem jest dla mnie to, że nie mam bezpośredniego kontaktu z klientami biblioteki, pracuję na zapleczu. Praca wymaga dużego skupienia i cierpliwości, choć bywa dość monotonna.

...sprawia mi przyjemność, nie idę do pracy - bo muszę, lecz - bo chcę, lubię to, co robię, lubię opracowywanie książek, rozwiązywanie problemów związanych z baza, wyszukiwanie książek do zakupu itd.

Jest spełnieniem moich marzeń, praca jest równocześnie moim hobby. Robię to, co lubię!!! 
Część osób nie potrafiło jednoznacznie ocenić swojego stosunku do wykonywanej pracy: „Tak i nie. Tak: lubię pracować i realizować swoje ambicje $w$ tej branży. Nie: relacje interpersonalne $z$ kierownictwem (mobbing)", "Jest bardzo ciekawa i rozwijająca, ale zdecydowanie za mało płaca, bo bibliotekarze są jedynym chyba przypadkiem w Polsce, gdzie tak wysokie wykształcenie w zawodzie ceni się tak mało".

Niewielki procent ogółu respondentów wybrało odpowiedź negatywną. Najważniejszym powodem były niskie zarobki, „niewspółmierne do wykonywanej pracy", brak perspektyw rozwoju zawodowego, monotonia i marazm. Nie lubią swojej pracy także z następujących powodów:

Nie znoszę tej całej formy, tej bibliotecznej rzeczywistości, niekompetentnej kadry zarządzającej (w tym kierowniczej), warunków pracy, w tym finansowych.

Mam uczucia ambiwalentne. Początkowo lubiłam pracę bibliotekarza, uważałam ją za potrzebna, zawsze traktowałam jako służbę. Teraz coraz częściej odczuwam dyskredytację zawodu zarówno ze strony otoczenia zawodowego, jak i - a może przede wszystkim - ze strony władz uczelni.

Środowisko jest dość hermetyczne i zamknięte na nowości. Brakuje młodych kierowników, tłamsi się własną inwencję i pomysły. Praca w bibliotece jest mało rozwojowa (choć mogłaby taką nie być).

Wciąż podcinane skrzydła. Praca staje się rutynowa i po pewnym czasie męcząca. Niskie wynagrodzenie i brak motywowania pracownika przekłada się na zniechęcenie i rozgoryczenie. Jeśli są zachęty do tzw. udzielania się, czy to naukowo, czy w inny sposób, to nie ma to odzwierciedlenia w jakiejkolwiek pomocy (finansowej czy też odpowiednim ułożeniem warunków w pracy, kiedy pracownik podejmuje się studiów podyplomowych, kursów dokształcających). A jeśli już poziom wykształcenia jest podniesiony, to i tak nie gwarantuje to wyższego wynagrodzenia w tej biednej branży. Pozycja bibliotekarza jest wciąż mało znacząca w środowisku, abyśmy byli poważnie brani pod uwagę.

Młodzi nie mają szans wybicia się, w pracy panuje zła atmosfera. Starsze panie bibliotekarki nie mają pojęcia o współczesnym bibliotekoznawstwie i boją się konkurencji młodych. Atmosfera w pracy jest nieprzyjemna, zdarzało się już, że młodzi oskarżali osoby z większym stażem o mobbing, za co niestety musieli odejść z pracy, albo zmienić dział.

[...] jestem niedoceniana - i przez dyrektora (który z zawodu nie jest bibliotekarzem), i w środowisku lokalnym (które nie uważa profesji, którą się zajmuję 
ani za szczególnie ciężka, ani za wymagającą JAKICHKOLWIEK kwalifikacji ot, „wydaj książkę - odbierz książkę"); bo zarabiam nieznacznie więcej niż zatrudnione u nas sprzątaczki (sic!!!); bo nie rozwijam się zawodowo - kursy, szkolenia czy nawet studia podyplomowe NIC nie zmieniają ani w mojej pozycji zawodowej, ani w widełkach płacowych; bo jestem sfrustrowana. A wybrałam ten zawód ŚWIADOMIE i kiedyś LUBIŁAM swoja pracę...

\section{Decyzje dotyczące pracy w zawodzie}

Kolejne pytania dotyczyły motywów podjęcia pracy w zawodzie bibliotekarza oraz powodów ewentualnej zmiany pracy. Respondenci i tu mieli możliwość zaznaczenia więcej niż jednej odpowiedzi.

Tabela 1. Podaj powody, dla których wybrałeś zawód bibliotekarza

\begin{tabular}{|l|c|c|c|}
\hline \multicolumn{1}{|c|}{ Odpowiedź } & $\begin{array}{c}\text { A } \\
\text { wiek do 30 lat }\end{array}$ & $\begin{array}{c}\text { B } \\
\text { wiek powyżej 30 lat }\end{array}$ & Ogółem \\
\hline Przez przypadek & 170 & 241 & 411 \\
\hline $\begin{array}{l}\text { Wydawało mi się, że to praca } \\
\text { łatwa, niewymagająca wysiłku }\end{array}$ & 25 & 15 & 40 \\
\hline Lubię książki & 225 & 318 & 543 \\
\hline $\begin{array}{l}\text { Zawsze chciałem/chciałam być } \\
\text { bibliotekarzem }\end{array}$ & 75 & 147 & 222 \\
\hline Tradycje rodzinne & 28 & 41 & 69 \\
\hline Inne & 80 & 74 & 154 \\
\hline
\end{tabular}

Dla ankietowanych najważniejszym powodem wyboru zawodu bibliotekarza był kontakt z książką (543), ale też wielu respondentów podało, że był on dla nich przypadkowy (411). Osoby z grupy A częściej niż pozostałe wybierały odpowiedź „,wydawało mi się, że to praca łatwa, niewymagająca wysiłku", ale w rezultacie i tak zaznaczył ją znikomy procent ogółu ankietowanych (25 osób). Inne powody to m.in.: praktyczne wykorzystanie swojej wiedzy, możliwość rozwoju zawodowego, chęć sprawdzenia się w tym zawodzie, bliskie powiązania $\mathrm{z}$ innym wykształceniem humanistycznym, zachętą była także ciekawa oferta studiów. W kilku wypadkach były to przyczyny zdrowotne, uniemożliwiające pracę w niektórych zawodach.

Ankietowani uzasadniali wybór także w następujący sposób: „wydawało mi się, że będzie to praca, która spełni moje wszystkie oczekiwania”, ,to dzięki stażowi pokochałam tę pracę... i zapragnęłam pracować w tym zawodzie”, ",nie dostałam pracy w wymarzonym zawodzie, którym obecnie stała się praca w bibliotece”, ,miałam przekonanie, że praca w bibliotece może 
dostarczyć wiele satysfakcji i zadowolenia oraz stwarza możliwości własnego rozwoju...", , "powody ekonomiczne, uczelnia kształcąca bibliotekarzy znajdowała się w moim mieście”, "cenię sobie przede wszystkim komfort psychiczny i swój czas wolny. Wydawało mi się, że to jeden z najmniej stresujących zawodów i nigdy nie trzeba pracować w domu, po godzinach", "zawsze pasjonowały mnie biblioteki, były dla mnie wyjątkowym miejscem", „chciałam pójść na studia humanistyczne, ale dające konkretny zawód. W trakcie studiów przekonałam się, że praca bibliotekarza jest bardzo ciekawa”, ,jako nauczycielka w średnim wieku miałam problemy z głosem musiałam się przekwalifikować”, „interesuję się literatura, historią. Zawód bibliotekarza daje możliwość poruszania się w obszarze moich zainteresowań”, ,,wybrałam ten kierunek studiów, mając na jego temat niewielkie pojęcie. Jak większość ludzi zresztą. Zaczynając studia, nie zdawałam sobie sprawy ze zmian, jakim podlegają obecnie biblioteki. Nie wiedziałam, że praca w bibliotece może być tak różnorodna i wymagająca".

Wybór zawodu to często realizacja wcześniejszych planów i marzeń: ,jak byłam mała, często bawiłam się w bibliotekarkę, uwielbiałam przebywać w bibliotekach, lubię ich klimat", ,zawsze chciałam pracować z książką (wydawnictwo, biblioteka, księgarnia)", choć niektórym przyniósł rozczarowanie: „myślałam, że będę miała fajna, stateczną, spokojną pracę... na starość. Nic się nie zgadza".

Tabela 2. Podaj przyczyny, dla których pracujesz w bibliotece

\begin{tabular}{|l|c|c|c|}
\hline \multicolumn{1}{|c|}{ Odpowiedź } & $\begin{array}{c}\text { A } \\
\text { wiek do 30 lat }\end{array}$ & $\begin{array}{c}\text { B } \\
\text { wiek powyżej 30 lat }\end{array}$ & Ogółem \\
\hline $\begin{array}{l}\text { Zawsze chciałem/chciałam praco- } \\
\text { wać w bibliotece }\end{array}$ & 95 & 145 & 240 \\
\hline $\begin{array}{l}\text { Jest to zgodne z moimi } \\
\text { zainteresowaniami }\end{array}$ & 238 & 382 & 620 \\
\hline $\begin{array}{l}\text { Mam dostęp do nowości } \\
\text { wydawniczych }\end{array}$ & 115 & 168 & 283 \\
\hline $\begin{array}{l}\text { W pracy mam czas na czytanie } \\
\text { książek }\end{array}$ & 19 & 12 & 31 \\
\hline Ze względu na panującą atmosferę & 135 & 131 & 266 \\
\hline Nie mogłem znaleźć innej pracy & 55 & 85 & 140 \\
\hline Inne & 95 & 112 & 207 \\
\hline
\end{tabular}

Jako odpowiedź na pytanie „dlaczego pracujesz w bibliotece?”, zdecydowanie najwięcej osób (620) podało zgodność ze swoimi zainteresowaniami. Dla wielu ważny jest dostęp do nowości wydawniczych (283) oraz 
realizacja wcześniejszych planów i marzeń (240). Bardzo istotną sprawą jest atmosfera w pracy (266). W stosunku do ogółu respondentów więcej głosów w tym wypadku było z grupy A (135). Ciekawostkę może stanowić fakt, że niewielki procent ankietowanych (19 osób) ma „w pracy czas na czytanie książek”. Statystycznie zaznaczyło ją więcej osób młodych (12). Część ankietowanych przy tym pytaniu wyraziło swoje oburzenie: „ja nie mam czasu w pracy na czytanie książek!”. Z innych przyczyn najczęściej podawano kontakt z innymi ludźmi, szczególnie z dziećmi i młodzieża, oraz usytuowanie biblioteki blisko miejsca zamieszkania.

Dosyć często praca w bibliotece jest wynikiem przypadku: „nadarzyła się okazja, więc chciałam spróbować i tak pracuję już 4. rok”, „zbieg okoliczności”, "po prostu muszę gdzieś pracować nawet za tak niskie pobory”, „praca przypadkowa, ale nie zmieniłabym jej na inną”, ,najłatwiej było mi znaleźć pracę w zawodzie", "początek to przypadek, potem odkrycie możliwości wykonywania bardzo ciekawej pracy, przy bardzo zmieniających się metodach pracy w bibliotece...", "zmęczenie pracą w szkole, szybki dostęp do literatury potrzebnej podczas studiów polonistycznych", „ta instytucja jako pierwsza odpowiedziała na moje CV", "skończone nieodpowiednie studia: filozofia”, "złapałam bakcyla bibliotekarskiego i zostałam".

Praca w bibliotece spowodowała u niektórych ankietowanych zmianę poglądów o zawodzie:

Wcale nie jest to łatwa praca i nie mam czasu na czytanie książek w pracy, ale pracowałam w kilku firmach m.in. prywatnych i wróciłam do biblioteki, myślę, że ze względu na książki i czytelników.

Obecnie nie wyobrażam sobie innej pracy i chciałabym w tym zawodzie dotrwać do emerytury.

Studia bibliotekoznawcze i praktyki zawodowe uświadomiły mi, jak bardzo praca w bibliotece różni się od powszechnego stereotypu. Znalazłam tu niszę dla siebie, robię to, co lubię, mogę się rozwijać. Pracuję przy komputerze, doskonalę swoją znajomość programów potrzebnych przy opracowaniu wsadu do BC [biblioteki cyfrowej], muszę być na bieżąco z aktualnymi standardami dotyczącymi digitalizacji, formatu metadanych itp. Mam poczucie, że jest to praca „na czasie” i że robię coś potrzebnego.

Pracowałam w bibliotece przed [nastaniem] komputeryzacji i uznałam tę pracę za niedającą satysfakcji. Po kilkuletniej pracy w innych zawodach przekonano mnie, że praca w bibliotece skomputeryzowanej to zupełnie inna jakość. 
Dodatkowo uzasadniano i wskazywano na inne przyczyny: „praca w tej samej miejscowości, opieka nad małym dzieckiem, pierwsze zatrudnienie w niepełnym wymiarze czasu”, ,spełniałem wymagane kwalifikacje”, , "miała to być praca na chwilę, na kilka miesięcy, żeby znaleźć później coś, co będzie mnie bardziej interesowało...", „pół roku byłam bez pracy i każda oferta pracy była lepsza od perspektywy pobierania zasiłku i zarejestrowania się jako bezrobotna", "mogę się rozwijać naukowo", ,jest zgodna z moim wykształceniem, czuję się w niej kompetentna”, ,"lubię się uczyć, praca w moim oddziale pozwala na poznawanie nowych narzędzi, doskonalenie umiejętności wyszukiwania informacji w bazach danych, źródłach elektronicznych, [umożliwia] pracę z użytkownikiem”, ,"teraz to już rodzaj przywiązania i przyzwyczajenia, to jak stare, choć nie zawsze dobre małżeństwo".

Tabela 3. Z jakich powodów byłbyś skłonny zmienić pracę?

\begin{tabular}{|l|c|c|c|}
\hline \multicolumn{1}{|c|}{ Odpowiedź } & $\begin{array}{c}\text { A } \\
\text { wiek do 30 lat }\end{array}$ & $\begin{array}{c}\text { B } \\
\text { wiek powyżej 30 lat }\end{array}$ & Ogółem \\
\hline Wyższe wynagrodzenie & 343 & 448 & 791 \\
\hline Potrzeba zmian & 165 & 171 & 336 \\
\hline Możliwość szybkiego awansu & 103 & 85 & 188 \\
\hline $\begin{array}{l}\text { Chciałbym prowadzić własną } \\
\text { działalność }\end{array}$ & 62 & 53 & 115 \\
\hline Inne & 68 & 111 & 179 \\
\hline
\end{tabular}

Najważniejszym powodem ewentualnej zmiany pracy dla zdecydowanej większości (791) ogółu respondentów było wynagrodzenie. Osoby młode, częściej niż starsze, podawały również możliwość szybkiego awansu (103) oraz prowadzenie własnej działalności (62). Do zmiany pracy byliby skłonni także z następujących powodów:

- zawodowych - brak satysfakcji z wykonywanej pracy i możliwości dokształcania się oraz podnoszenia kwalifikacji, rozpoczęcie pracy naukowej, znalezienie pracy w wyuczonym zawodzie, nadmiar obowiązków przypadających na jedną osobę, zła atmosfery w pracy, zmiana na pracę bardziej inspirującą i twórcza, praca w systemie jednozmianowym lub dogodniejsze godziny (wolne soboty i niedziele), uciążliwe kontakty z użytkownikami lub brak kontaktów z czytelnikami w przypadku pracy w agendach (tj. gromadzenie, opracowanie), higiena pracy, np. zbyt długie przebywanie przy komputerze; 
- prywatnych - sytuacja rodzinna, zmiana miejsca zamieszkania, zatrudnienie w bibliotece znajdującej się bliżej miejsca zamieszkania, możliwość pracy w domu, w czasie nienormowanym.

Ankietowani dodatkowo uzupełniali wypowiedzi o własne opinie:

Mogłabym zmienić pracę, ale nie zawód. Byłabym gotowa dla lepszych perspektyw rozwoju, dla pracodawcy, który byłby gotów inwestować we mnie i doceniał moje zaangażowanie, a także dla wyższego wynagrodzenia.

Zmieniłabym na pracę w bardziej koedukacyjnym towarzystwie.

Nie lubię pracować $\mathrm{z}$ ludźmi i w grupie. Wolę pracę $\mathrm{w}$ domu w dowolnych godzinach.

Gdyby praca przestała mnie satysfakcjonować, tzn. nie miałabym nowych zadań, biblioteka rozwijałaby się zbyt wolno, byłabym odsunięta od pracy w informacji naukowej do działu, w którym nie miałabym szansy wykorzystać moich umiejętności i zainteresowań. Myślę, że zarobki z czasem też będą miały coraz większe znaczenie.

W pracy jak i w życiu lubię zmiany, chcę się rozwijać. Zmianę pracy musiałabym rozważyć i przeanalizować bilans zysków i strat. Jak na razie pracy nie zamierzam zmieniać, bardzo mi się podoba.

Zmieniłabym pracę, gdyby okazało się, że mam możliwość pracy w zgranym, i przede wszystkim dobrze zarządzanym zespole uczciwych i pełnych inicjatywy ludzi a równocześnie większych zarobków dających swobodę w planowaniu życia rodzinnego.

Wiele osób przy tym deklarowało: „lubię swoją pracę i nie zamienię jej na żadną inną", "[zmiana] wyłącznie w razie zwolnienia mnie z pracy", "obecnie żadne powody nie skłoniłyby mnie do zmiany pracy”, ,nie byłabym skłonna za żadne skarby świata".

Satysfakcję z wynagrodzenia pokazuje zamieszczony wykres (rys. 12). Zarówno w grupie A, jak i w grupie B procentowo przedstawia się on dosyć podobnie. Z ogólnej liczby ankietowanych zadowolonych ze swojego uposażenia jest $17 \%$ (w tym bardzo zadowolonych $2 \%$, w grupie A zaledwie 1\%).

Wysokość oczekiwanego wynagrodzenia netto, jak widać na wykresie (rys. 13), najczęściej oscyluje wokół kwoty 2000-2500 zł. Tak podało 31\% 


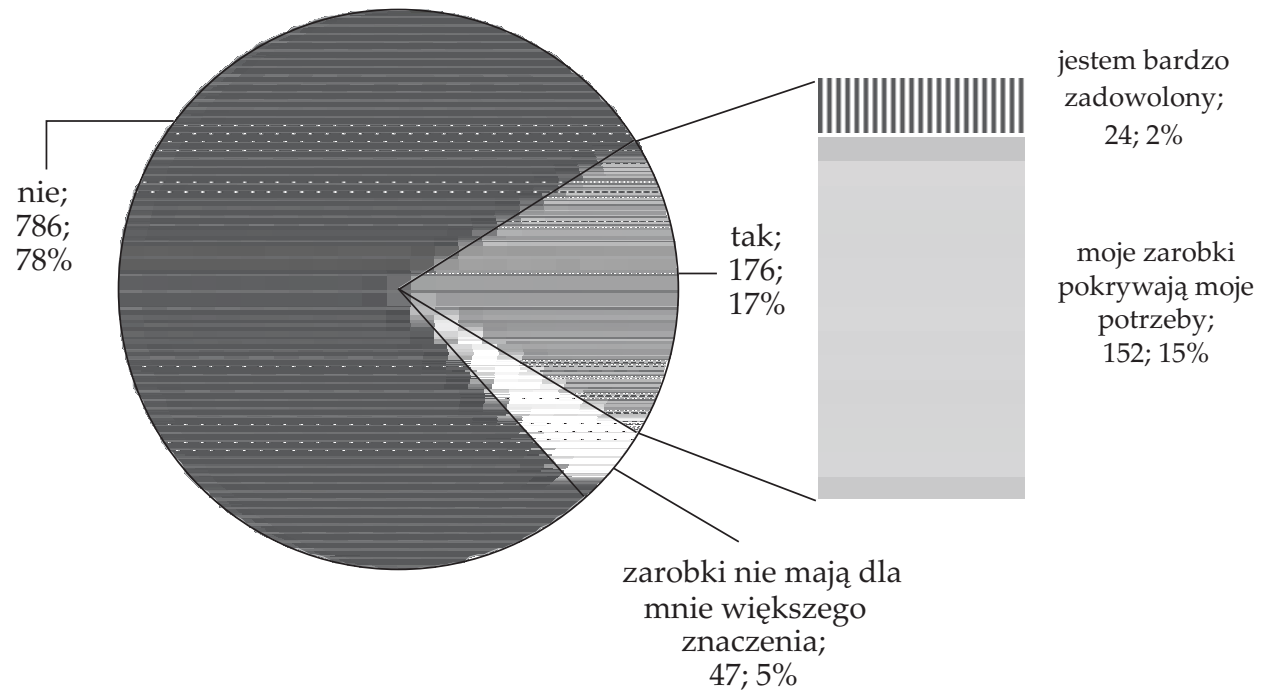

Rys. 12. Czy jesteś zadowolony ze swojego uposażenia?

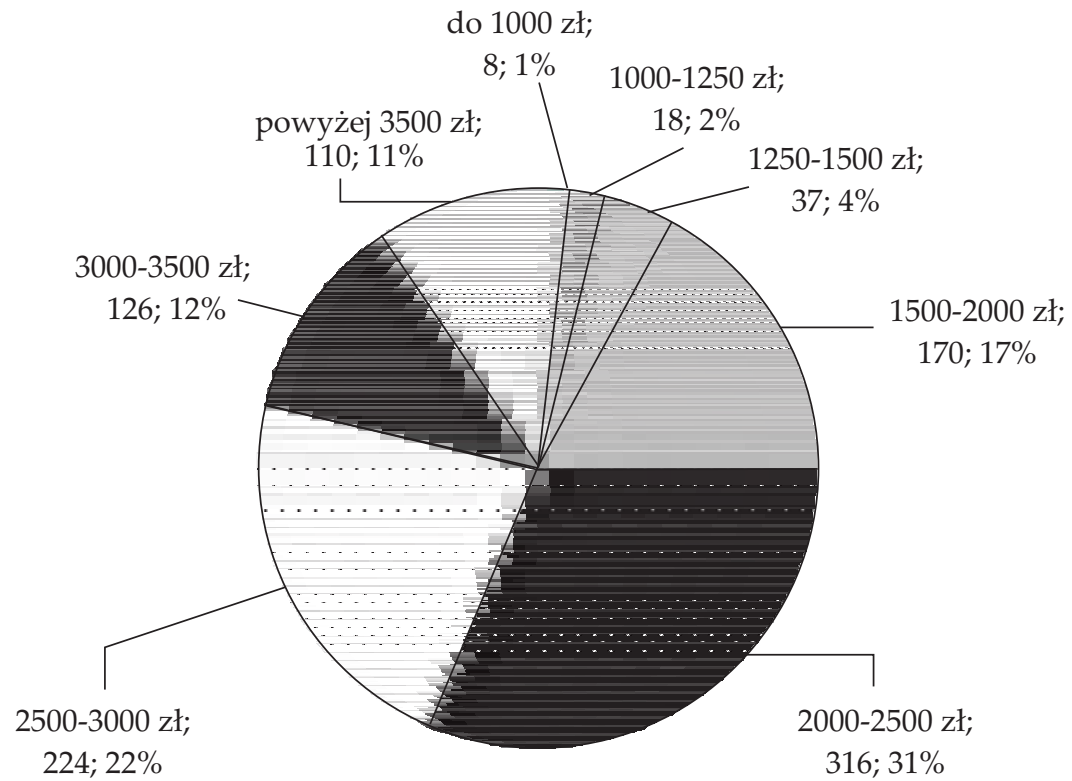

Rys. 13. Jaka wysokość wynagrodzenia byłaby dla Ciebie satysfakcjonująca?

ogółu respondentów i najwięcej w grupie A (rys. 14). Na wartość 2500-3000 zł wskazało 22\% wszystkich ankietowanych. Z tej opcji zdecydowanie najbardziej zadowolone byłyby osoby z grupy B (27\%). Około 11\% wszystkich bibliotekarzy biorących udział $\mathrm{w}$ badaniach chciałoby zarabiać powyżej 3000 zł netto (w grupie A tylko 4\%). 


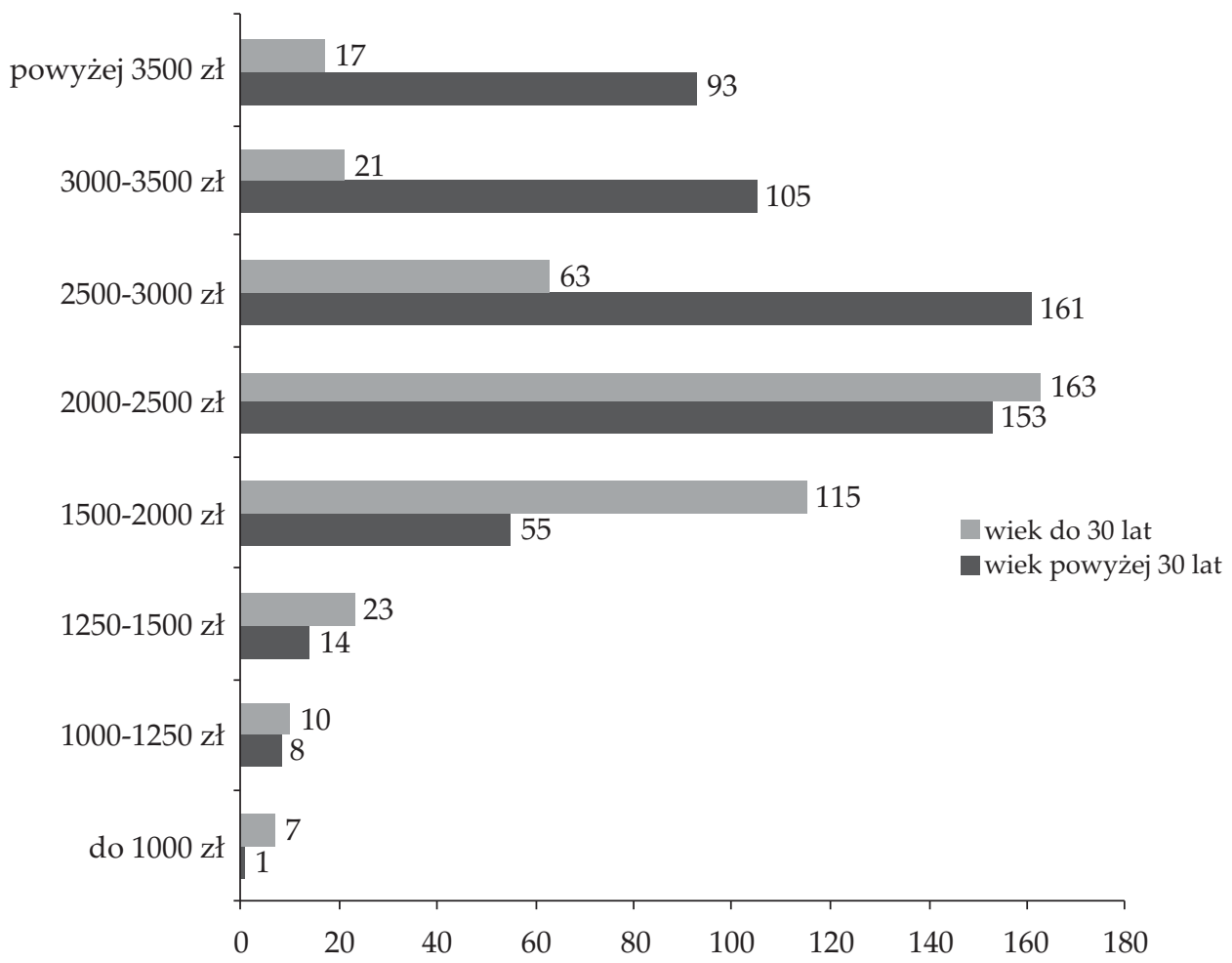

Rys. 14. Jaka wysokość wynagrodzenia byłaby dla Ciebie satysfakcjonująca?

Ostatnie omawiane pytania dotyczyły planów na przyszłość. Pomimo wyraźnego niezadowolenia z wysokości zarobków, co wykazały prezentowane wykresy, ankietowani najczęściej zaznaczali odpowiedź: „nie oczekuję większych zmian, ta praca mi odpowiada", chociaż wiele osób, głównie w grupie A, podało, że „chcieliby szybko awansować”. Wskazywali także na swoje zainteresowanie pracą naukową (rys. 15).

Podnoszenie kwalifikacji, egzamin na bibliotekarza dyplomowanego, nauka języków obcych, dodatkowa praca to najczęściej wymieniane inne plany zawodowe ankietowanych. Wśród nich znalazły się także następujące wypowiedzi:

Aktualna praca bardzo mi się podoba, chciałabym jednak zdobyć dodatkowe wykształcenie, alternatywny zawód, żeby zwiększyć swoje szanse na rynku pracy. Mam świadomość, że dziś mało kto pracuje w jednym zawodzie przez całe życie. Obawiam się również, że rosnące koszty utrzymania zmuszą mnie do szukania pracy lepiej płatnej, choć może mniej atrakcyjnej.

Chciałabym zrealizować moje pomysły na obecnym stanowisku. 


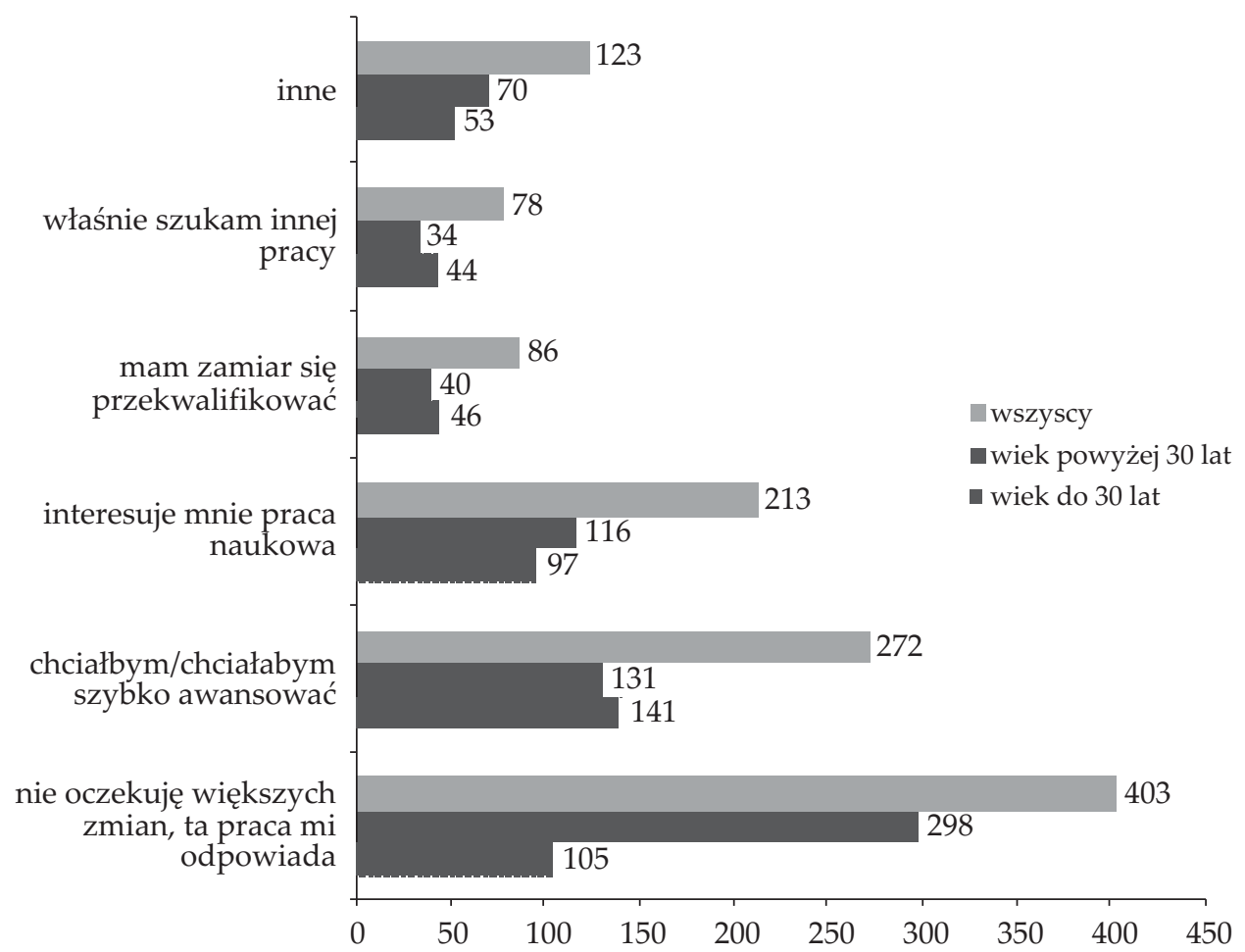

Rys. 15. Jakie są twoje zawodowe plany na przyszłość?

Być może zdecyduję się na przejście do firmy infobrokerskiej, bo tam będę mogła robić to, co umiem i lubię za dużo wyższe pieniądze.

[Chciałabym] zmienić wizerunek biblioteki, uporządkować panujący od 50 lat bałagan.

[Interesuje mnie] praktyka w zagranicznej placówce, aby mieć większą wiedzę.

Dodatkowo podniesienie kwalifikacji zawodowych o wykształcenie w kierunku historia regionu - będzie przydatne w procesie tworzenia działu zbiorów o regionie oraz podczas prowadzenia samodzielnych badań nad zagadnieniami z historii regionu.

Ustabilizowanie sytuacji zawodowej. W dalszej przyszłości nie wykluczam zmiany pracy na lepszych warunkach (ale także w charakterze bibliotekarza).

Jeżeli nic nie zmieni się w kwestii wysokości wynagrodzenia, będę zmuszona wykorzystać swoje kwalifikacje ekonomiczne, ale jest to trudna decyzja (zado- 
wolenie z wykonywanego zawodu czy odpowiednie wynagrodzenie za dobrze wykonaną pracę i przyzwoitą egzystencję rodziny).

Oczekuję dziecka i w związku z tym na razie nie pracuję i zastanawiam się nad tym, co dalej, chociaż lubię swoją pracę, mam momenty zniechęcenia i trochę przeraża mnie myśl, że przez kolejne 20 lat będę robić to samo.

Przeprowadzimy się na wieś. Chciałabym rozwinąć swoje zainteresowania i może dzięki nim dokładać się do budżetu rodzinnego, ale to w dalszej, dużo dalszej perspektywie, 10 lat, może później. Obecnie praca mi bardzo odpowiada, ale też i powoli rozwijam się, tzn. przekwalifikowuję. W ciągu najbliższych kilku lat nie mogę zmienić pracy. Muszę odpracować umowę zawartą w szkole.

Dalszy samorozwój. Podjęcie studiów podyplomowych z zakresu zarządzania zasobami ludzkimi i komunikacji społecznej. Plany aby podjąć też studia z zakresu dziennikarstwa.

Jeżeli nie będzie możliwości mojego rozwoju i rozwoju biblioteki, to będę szukać innej pracy, nawet za granicą.

Chciałabym jedynie, aby moja biblioteka miała większy lokal, a co za tym idzie lepsze warunki do rozwoju współpracy z czytelnikami.

Z jednej strony bardzo odpowiada mi moja praca, a z drugiej - chciałabym wrócić do biblioteki publicznej (to była moja pierwsza praca) jako kierownik, żeby móc działać, coś zmieniać, mieć większy kontakt ze środowiskiem lokalnym, by móc wpłynąć na opinię ludzi o tym zawodzie (z poprzedniej pracy pod tym kątem mam przykre doświadczenia).

Kończę drugie studia podyplomowe. Od października zaczynam roczny kurs z języka niemieckiego.

Chciałabym jeszcze bardziej rozwinąć działalność naszej placówki - więcej spotkań z literatami, planuję w przyszłości organizować większe imprezy.

Jestem dyrektorem placówki, ale chciałabym sprawić, żeby współpracownicy też byli pasjonatami zawodu.

Po habilitacji (mam stopień doktora nauk humanistycznych) - praca w szkole wyższej na stanowisku samodzielnego pracownika naukowego. 


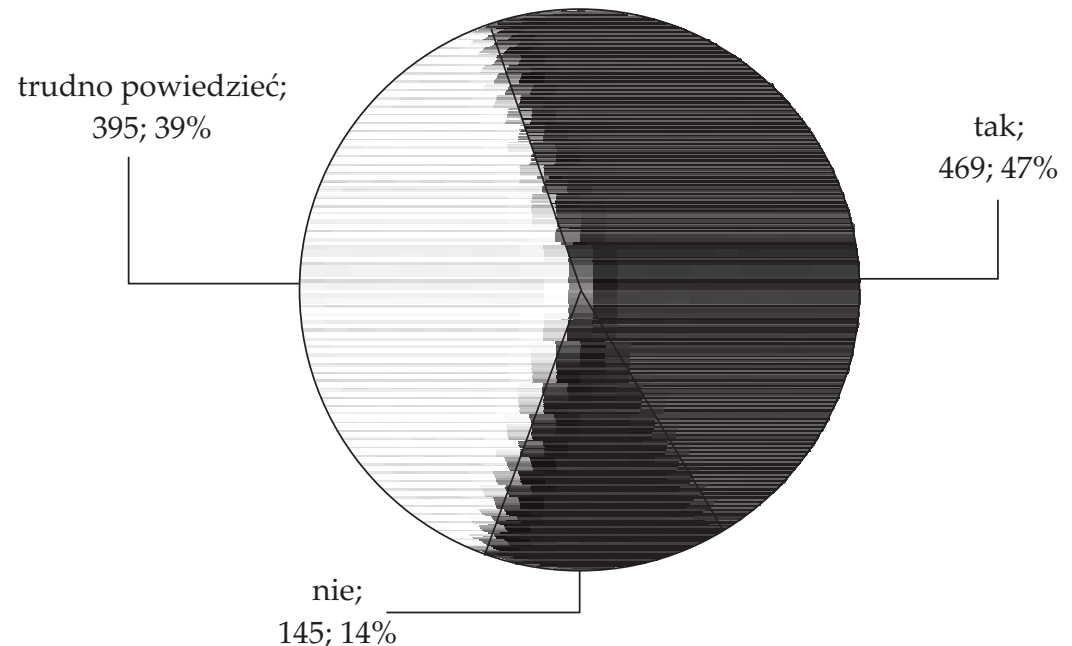

Rys. 16. Gdybyś miał jeszcze raz możliwość podjęcia decyzji dotyczącej wyboru pracy zawodowej, czy zdecydowałbyś się na zawód bibliotekarza?

W stosunku do pytania poprzedniego konsekwentnie rozkładał się udział odpowiedzi na hipotetyczne stwierdzenie dotyczące życiowej decyzji wyboru zawodu (rys. 16). Najwięcej, bo 47\% ankietowanych odpowiedziało, że gdyby musieli raz jeszcze zdecydować o wyborze zawodu, byłby to zawód bibliotekarza, $14 \%$ wybrałoby inną pracę. W obu grupach wiekowych wynik procentowy był podobny.

\section{Opinie na temat wykonywanego zawodu}

Ostatnim pytaniem merytorycznym były refleksje na temat zawodu bibliotekarza. Z możliwości wypowiedzi skorzystały 503 osoby. Najczęściej wspominano tu o negatywnym stereotypie bibliotekarza panującym w ich opinii, szczególnie w środowisku bibliotek akademickich, także o braku autorytetu, niedocenianiu roli bibliotekarza i jego pracy. Wielokrotnie też pada stwierdzenie, że jest to ciężka, słabo płatna praca. Mimo że duża liczba wpisów zawiera wymienione ujemne strony zawodu, to prawie w każdej wypowiedzi respondenci wyraźnie podkreślają, że praca w zawodzie daje im ogromną satysfakcję. Oto najciekawsze refleksje:

Zawód ten wymaga dużego wkładu intelektualnego, a pomimo tego nie jest zawodem prestiżowym. Społeczeństwo nie docenia bibliotekarzy. 
Stoimy przed dużym wyzwaniem - rozwój technologii cyfrowej zmienił rolę bibliotek i zadania, przed jakimi stoją dziś bibliotekarze. Musimy w tym nowym świecie znaleźć miejsce dla siebie, żeby nie wypaść z obiegu.

Zawód niedoceniany a zacny. Część kadry trafiła do biblioteki w wyniku negatywnej selekcji, część dopiero się dokształca, większość reprezentuje niski poziom (kultury i wykształcenia), to oni budują zły wizerunek zawodu.

Teoria zawodu fascynująca, z praktyką dużo gorzej. Drażnią mnie przypadkowi ludzie pracujący w bibliotekach, mający zawód w pogardzie. Boli poczucie, że nawet $\mathrm{w}$ bibliotekach bibliotekoznawstwo nie jest poważane.

Zawód niedoceniany, źle opłacany, bez perspektyw, skostniały, pełen niekompetentnych ludzi, którzy kształtują wizerunek bibliotekarza w oczach społeczeństwa, zawód dla hobbistów, prowadzący ostatecznie do depresji.

Jest to zawód, o którym przeciętni czytelnicy myślą - miły, łatwy i przyjemny. Tymczasem współczesny bibliotekarz to m.in. animator kultury, osoba o wszechstronnych zainteresowaniach, przewodnik po świecie informacji.

Zawód wymagający poświęcenia, który wykonując, muszę kochać, bo zarobki nie są rewelacyjne i samotna osoba nie jest $\mathrm{w}$ stanie się z nich utrzymać.

W ciągu tych przepracowanych lat zauważyłam, że pracujący w bibliotekach dzielą się na bibliotekarzy i zatrudnionych jako bibliotekarze, ci ostatni nie powinni pracować.

Duże wymagania, jeśli chodzi o wykształcenie, umiejętności, pracowitość, sumienność, dostosowywanie się do rosnących wymagań i jednocześnie bardzo niskie płace, brak docenienia społecznego i dość sztywna hierarchia.

Moje wyobrażenie o pracy w bibliotece zmieniało się wraz z każdym rokiem w niej przepracowanym. Teraz wiem, ile wysiłku, energii i niekończących się pomysłów jestem w stanie z siebie wykrzesać.

Dalej jest zawodem niedocenianym, gdzie społeczności wydaje się, że w bibliotece nie trzeba wiele umieć, a pracownicy są mało wyedukowani.

Wynagrodzenie to koszmar, to praca dla kobiet, których mąż ma dobrą pracę i pensję. 
Ciekawa praca dla singli, lubiących mało zarabiać, lub dla osoby, której partner/ka bardzo dobrze zarabia. Brak większej odpowiedzialności.

Moim zdaniem w bibliotekach powinny pracować osoby z predyspozycjami i kwalifikacjami do tego zajęcia. Nie powinny to być osoby przypadkowe, które po prostu nie mogą znaleźć zatrudnienia gdzie indziej.

Wymarzona praca dla mnie teraz, nieabsorbująca tzn. „nie zabieram stresu z pracy do domu" a sam zawód? Cóż, miło jest pomyśleć, że może ktoś się rozwija, bo sobie tutaj siedzę.

Spełnia moje oczekiwania, mam możliwość rozwoju w wielu dziedzinach wiedzy. W tym zawodzie nie można się nudzić.

Gdyby nie niskie zarobki i trudne warunki lokalowe, byłoby super.

Źle się dzieje w zawodzie we wszystkich jego aspektach... Wdawanie się w szczegóły to temat na książkę.

W mojej miejscowości jest to zawód w miarę szanowany.

Pracownikom z niskim wynagrodzeniem trudno jest zdobyć wykształcenie wyższe na uczelniach, które są oddalone od miejsca zamieszkania często setki kilometrów.

Bibliotekarz powinien być kreatywny, twórczy, ciągle doskonalić swoje umiejętności. Powinien lubić swoich czytelników, być miły, sympatyczny. Mam wrażenie czasem, że niektórzy siedzą w bibliotekach za karę.

Nie zgadzam się z ogólnie znanym stereotypem bibliotekarza! Dzięki tej pracy można się wiele nauczyć i samemu pracować nad rozwojem...

Fantastyczna praca z czytelnikiem, tylko że trudno utrzymać rodzinę.

To jest zawód dla osób, które lubią ludzi. Praca czasami jest żmudna i monotonna, ale niestety jest często niedoceniana przez ludzi no i przez rządzących.

Minusy: 1) zawód bez szacunku społecznego, 2) brak koncepcji ogólnopolskiej na ważne problemy bibliotekarzy, 3) niski próg odpowiedzialności za pracę 3) niskie zarobki. Plusy: 1) brak stresu, 2) przestrzeń dla własnych badań, 3) życzliwa atmosfera. 
Zawód dla osób zdyscyplinowanych, skrupulatnych, otwartych na ludzi i nowości technologiczne. Dający satysfakcje. Jedyny minus to małe zarobki i brak społecznego poparcia i prestiżu pracy.

Zawód o wielkim potencjale możliwości (nieczęsto wykorzystywanym). Wymagający podążania z duchem czasu. Lekceważony w społeczeństwie.

Myślę, że to piękny i cudowny zawód. Kocham książki i pracę z ludźmi.

Aby być dobrym bibliotekarzem, trzeba po prostu lubić swoją pracę.

\section{Wnioski}

Analiza badań ankietowych wykazała, że metody poszukiwania pracy zmieniały się na przestrzeni ostatnich lat (porównanie odpowiedzi grup A i B). Wyraźnie zauważalne są tendencje do korzystania z możliwości Internetu - szukanie na portalach specjalizujących się w pośrednictwie pracy, rozsyłanie do bibliotek pocztą e-mailową swoich aplikacji o pracę, zamieszczanie na osobistych stronach domowych ogłoszeń z informacjami o poszukiwanej pracy. Skuteczność tych metod bywa jednak różna.

Motywy wyboru zawodu pozostają niezmienne. Świadomy wybór podyktowany jest zamiłowaniem do książek, możliwością kontaktu z użytkownikami bibliotek oraz różnego rodzaju zainteresowaniami, które można realizować przy dostępie do książek, szczególnie nowości wydawniczych (dokształcanie się, publikacje, badania naukowe). Decyzje dotyczące wyboru zawodu nie zawsze podejmowane są świadomie, często decyduje przypadek. Szczególnie młodzi ludzie nie zdają sobie sprawy z wysokich wymagań, jakie są stawiane przyszłym pracownikom bibliotek. Zdecydowana większość respondentów byłaby skłonna do zmiany pracy pod warunkiem uzyskania wyższego wynagrodzenia. Osoby rozpoczynające pracę bywają często rozczarowane wysokością pierwszej pensji. Dla nich powodem zmiany pracy byłaby także możliwość szybkiego awansu.

Większość ankietowanych wiąże swoje plany zawodowe z pracą w bibliotece. Z ich wypowiedzi wynika, że nawet gdy zamierzają zmienić pracę, mają na myśli raczej pracę w innej bibliotece niż przekwalifikowanie się. Osoby młode chcą podnosić kwalifikacje, umiejętności, aby zwiększyć swoje szanse na awans i wyższe wynagrodzenie.

Liczne opinie wyrażane w przeprowadzonych badaniach najtrafniej będzie podsumować słowami respondentów: „Uważam, że jest to zawód dla 
ludzi z pasją”, „Można się naprawdę realizować w tym zawodzie, o ile rzeczywiście w kimś jest zapał i chęć pracy z ludźmi. Jeżeli tego nie będzie, to nadal będziemy postrzegani jako mało przebojowy zawód i dla ludzi zakompleksionych".

\title{
JADWIGA WOJTCZAK
}

\section{Librarians on the labour market - a discussion on the results of the questionnaire surveys}

\begin{abstract}
In spring 2009, a series of anonymous questionnaire surveys were carried out among Polish librarians and students of library science. The aim of the survey was to find out the current state of general attitudes towards the profession of the librarian, its position on the labour market and the expectations of the group of professional workers concerning the patterns of work remuneration. The survey included a group of over 1,000 people of different age from almost all regions of Poland. A great number of answers to the half-open questions made it possible to better understand the feelings and intentions of the respondents.
\end{abstract}

KEY wORDs: library profession, labour market, questionnaire survey 